\title{
HYBRID ZERO ENERGY HOUSES (ZEH) FOR FLORIDA'S HOT, HUMID CLIMATE
}

\author{
S.R. RUSSELL \\ University of South Florida.
}

\begin{abstract}
The building sector is responsible for a large percentage of the energy usage in the United States as a whole and Florida's buildings consume more energy than those in any other state in the country. Florida's hot humid climate presents challenges for the implementation and maintenance of energy efficient buildings but also offers opportunities to reduce building energy usage. Building technology has improved dramatically in recent years and photovoltaic technology has become affordable for individual site based generation of clean renewable energy making the dream of net zero energy houses [ZEH] a reality. After a brief history of energy efficient buildings in the United States, this paper discusses passive design strategies in Florida, advancements that have been made toward ZEH, and several cutting edge technologies that hold promise for the Florida ZEH of the future. This paper argues that although significant steps have been made toward their implementation, ZEH examples to date have not taken full advantage of Florida's mild climate. The author maintains that Florida ZEH can be designed to take advantage of the mild seasons as well as buffer against the seasons of severe heat and humidity with a hybrid open/closed building type that can improve on the advancements already made in ZEH design while promoting a comfortable, healthy indoor/outdoor lifestyle for Florida residents.
\end{abstract}

Keywords: clean renewable energy, emerging technologies, energy conservation, energy efficiency, Florida, green building, hot humid climate, sustainability, zero energy houses.

\section{INTRODUCTION}

Present day buildings consume more electrical energy than any other sector of the U.S. economy, including transportation and industry, and the consumption is increasing. More than half of the electric power in the United States is generated in coal burning plants, $70 \%$ is generated by fossil fuels, and less than $2 \%$ comes from clean renewable energy. Burning of fossil fuels releases many dangerous contaminants and green house gasses into the air, and because their supply is limited, the acquisition and distribution of fossil fuels around the world has led to greed, conflict, and political strife. In the State of Florida where the building sector accounts for $90 \%$ of the state's electric energy consumption, $51 \%$ is attributable to the residential sector alone, which translates into $6.4 \%$ of the entire country's residential electricity consumption [1]. As the population of Florida grows, the escalating demand for electrical power will force utility companies to build more generating capacity and put more stress on Florida's delicate eco-systems.

\subsection{Electricity use in Florida houses}

Florida's high per capita residential electricity demand is closely related to the climate. Florida is a peninsula located in the extreme southeast corner of North America from $24^{\circ}$ to $31^{\circ}$ latitude. The U. S. Department of Energy's [DOE] climate map puts Florida predominantly in zone 2A with the southern tip falling into zone $1 \mathrm{~A}$. Zone $2 \mathrm{~A}$ is defined as a humid subtropical climate having 3500-5000 cooling degree days. Table 1 shows the monthly temperature and relative humidity data for the City of Tampa, which is roughly in the middle of the state.

Similar climates can be found in other parts of the world in places like Okinawa Japan, southern China, and Bangladesh. Because of the hot temperatures and high humidity, Florida residents typically use air conditioning systems the year round. Typical air conditioner compressors consume 
Table 1: Average temperature and relative humidity, Tampa FL.

\begin{tabular}{ccccccccccccc}
\hline & Jan & Feb & Mar & Apr & May & Jun & Jul & Aug & Sep & Oct & Nov & Dec \\
\hline $\begin{array}{c}\text { Avg. High } \\
\text { Temp }{ }^{\circ} \mathrm{C}\end{array}$ & 21.4 & 22.2 & 24.7 & 27.5 & 30.6 & 32 & 32.3 & 32.4 & 31.6 & 28.9 & 25.2 & 22.3 \\
$\begin{array}{c}\text { Avg. Low } \\
\text { Temp }{ }^{\circ} \mathrm{C}\end{array}$ & 10.5 & 11.3 & 13.9 & 20 & 20 & 22.8 & 23.7 & 23.7 & 22.9 & 19.1 & 14.5 & 11.4 \\
$\begin{array}{c}\text { Avg. RH \% } \\
\text { at 1 pm }\end{array}$ & 60 & 57 & 56 & 52 & 53 & 61 & 64 & 65 & 63 & 58 & 58 & 60 \\
\hline
\end{tabular}

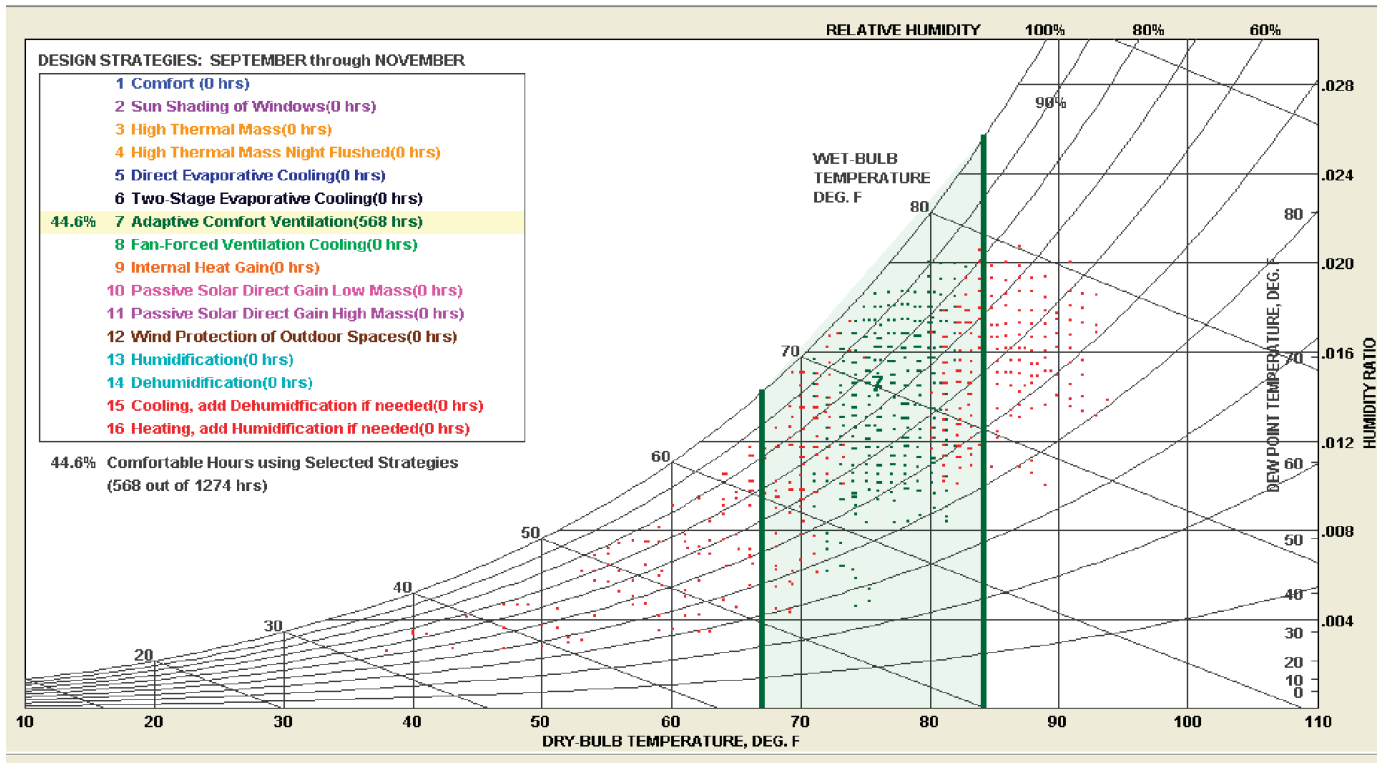

Figure 1: Psychrometric chart- Tampa, FL.

relatively large amounts of electricity when compared to other household appliances and equipment. The situation is aggravated by poor construction practices such as placing air handling units in hot attic spaces and using un-insulated concrete block for walls. Despite the hot temperatures during half of the year, Florida also enjoys balmy warm temperatures for roughly half of the year. The psychrometric chart in Fig. 1 shows that from September through November roughly $45 \%$ of the hours from 9 am until $10 \mathrm{pm}$ fall within the comfort zone [grey tone] established by ASHRAE for naturally ventilated buildings.

A similar study from February through April showed similar results with roughly $40 \%$ of the hours between 10 am and $7 \mathrm{pm}$ falling within the comfort zone. A slightly different time frame was sampled in the fall and spring due to daylight savings time used in the United States from mid-March until early November. This data shows that houses can be naturally ventilated for much of the spring and fall instead of the current practice of using air conditioning or heating year round. Shutting off mechanical systems and naturally ventilating houses in Florida would result in a significant reduction in electricity consumption. 


\subsection{Transforming residential energy use with ZEH}

The design and construction of energy efficient homes that function in harmony with the climate will help to bring Florida's escalating energy consumption under control and help protect the state's rich natural assets. Periods in Florida's history give us clues about how contemporary homes can be designed in harmony with the environment. In the 19th century without the luxury of air conditioning, the early settlers in Florida were forced to adapt their buildings to the hot humid climate. Later, in the mid-20th century, a group of Florida architects took the climatic strategies used in the early vernacular houses and applied them to homes designed for a contemporary lifestyle. Recently, researchers have proven that houses that minimize their energy use and employ site-based, clean renewable energy sources, can significantly reduce or eliminate their demand for electric power from municipal utilities (see Section 4). So-called zero energy homes implemented on a large scale would completely transform the current electric power distribution system, and result in a site based, distributed, electric generation scenario based on clean renewable energy. The reduced demand on public utilities would stem the need for increased generating capacity, relieving stress on the environment. An overview of the evolution of energy efficient buildings in the United States as a whole provides perspective on the current situation in Florida.

\section{EVOLUTION OF ENERGY EFFICIENT BUILDINGS IN THE UNITED STATES}

Attempts at reducing energy use in buildings began in the United States just before World War II with work at the Massachusetts Institute of Technology (MIT) on solar heated structures. The MIT Solar IV house, built in the late 1950s, was the fourth test house designed by a group of engineers known as the Space Heating Committee of the Solar Energy Conversion Project founded in 1938. Unlike modern photovoltaic solar cells, the cells on the MIT house were not designed to generate electricity. A 640-square foot collector tilted at a 60 degree angle provided for $57 \%$ of the building's heat during winter. Heat was stored in two basement water tanks of 1500 and 275 gallons. During the winter, the larger tank was heated by the circulation of solar heated water from the roof collectors. Water from the tank circulated through the coil of a heat exchanger to warm air blown over the coils and through the house. Water from the smaller tank was heated by an oil burner and used for supplementary heat on extra cold or cloudy days. During summer, the smaller tank was connected to the roof collectors to provide hot water for domestic use, and a low capacity refrigerator cooled the water in the larger tank to provide air conditioning [2].

\subsection{The passive solar movement}

A widespread and concerted effort to reduce energy use in United States homes was made during the energy crises of the 1970s. Ed Mazria's Passive Solar Energy Book was one of many publications written to make the concepts of passive solar design accessible to professionals and the average person alike. Mazria writes in the acknowledgments that at the time he began writing the book in 1975, 'information concerning passive solar design was virtually non-existent' [3]. Mazria's book introduced insulated, south-oriented glazing systems, Trombe walls, flat plate collectors, sunspaces, and roof ponds. Roof overhangs, once a feature of the vernacular architecture of many regions, were once again thought of as a necessary feature requiring precise design. The properties of materials, their thermal mass, and reflectivity became important considerations as did the natural circumstances

of the site and its micro-climate. In the state of Florida in the late 1970s, there was a revived interest in the vernacular Cracker house that had been all but forgotten until that time. University of Florida professor Ron Hasse spent years visiting and documenting the few remaining houses in the Florida 
countryside (see Section 3.1). Although rustic and almost banal in its simplicity the cracker house had many features that were adaptations to the Florida climate, making it an important precedent for passive design.

\subsection{Super-insulated houses}

At about the same time, researchers at the University of Illinois were trying to reduce the heating and cooling loads in buildings using highly insulated envelopes. The Lo-Cal House [low calorie] designed by Wayne Schick involved a computational study of how much energy could be saved with high levels of thermal insulation, airtight construction, and heat recovery ventilation. The proposed insulation values were R-60 ceilings, R-30 walls, and R-20 floors. The Lo-Cal House was designed to illustrate how good planning and construction detailing could reduce residential energy consumption. Although never built, the Lo-Cal House attracted a great deal of national publicity and was influential in subsequent built projects like the Leger House in Pepperell, MA, one of the first double-wall, super-insulated houses in the world. The heating bill for the Leger House in 1979 was \$38 and remained less than $\$ 50$ per year for the next 10 years [4]. The super-insulated house concept was adopted in Germany and refined to become the Passivhaus, a highly energy efficient house that can be heated largely by the incidental heat from appliances and the residents' body heat. The first Passivhaus was built in the United States in 2004 [5]. The sudden availability of information about passive solar design and super insulation coupled with the sudden high price of petroleum set off a temporary energy efficiency movement that spread to a small counter culture but never acquired the momentum necessary to make it a wide spread popular movement. By the time the oil crisis ended and energy prices returned to an affordable level, the construction of passive solar buildings all but died out. The solar houses of the 1970s had a certain functional aesthetic that was largely rejected by the architectural profession and the general public during the historicism of the postmodern 1980s. The lack of a perceived energy crisis seemed to deal a lethal blow to the short-lived energy efficiency movement in the United States.

\subsection{Photovoltaic technology}

First developed in the 1950s, photovoltaic panels were being tested on buildings in the 1970s but their high cost made them impractical for most applications. Throughout the late 1980s, the cost of solid state solar electricity production with photovoltaic (PV) panels declined in price such that the possibility of using PV for site-based, distributed generation became increasingly feasible [6]. This was due, in large part, to federally financed research and development projects that resulted in a reduction in PV module costs from $\$ 5.00$ per watt in the 1980 s to $\$ 1.50-\$ 2.50$ in 2000. The development of PV has been characterized by the battle between the cost and efficiency of converting solar radiation into electric power. Complex, triple junction photovoltaic cells used in satellites have reached efficiencies as high as $41.6 \%$, but their cost makes them prohibitive for use in buildings. Commercially available silicon crystal cells are more affordable at about $\$ 3.40$ per watt installed but efficiencies are only around 18\% [7]. The DOE has estimated that an installed cost of \$1/Watt [an equivalent of 5-6 cents per kilowatt hour] would make solar power, without subsidies, competitive with the wholesale price of electricity throughout the United States. The DOE's short term goal is to reduce the cost of solar power from the current price of $\$ 3.40 /$ Watt to $\$ 2.20 /$ Watt by 2016 . The DOE's Solar Energy Technologies Program's [SETP] PV subprogram is funding methods to advance all major PV cell technologies. These include wafer silicon ( $\mathrm{Si}$ ); amorphous and single-crystal, thinfilm Si; high-efficiency (III-V) semiconductors; cadmium telluride (CdTe), and copper indium gallium diselenide (CIGS) thin films, and advanced organic, and dye cells [8]. All of the technologies 
being pursued by SETP have pros and cons associated with their development and a detailed discussion of each is beyond the scope of this paper.

\subsection{Zero energy houses}

By the late 1990s, experimental houses were being built that combined high levels of energy efficiency with site-based photovoltaic electric power to provide most of the energy needs of a typical house. Many of the initial experiments were done as off-the-grid houses for areas where public utilities were not accessible. Off grid ZEH however, require expensive storage batteries to bridge the periods when the PV system is not producing electricity. Recently, more attention has been given to ZEH that are connected to the municipal electrical grid so they can send excess power to the utility companies during peak periods and take electricity back during the evening or on cloudy days when the PV system is not producing. With this give and take, a house can achieve a net zero energy usage when averaged over the course of a year without the use of expensive batteries.

\section{FLORIDA RESIDENTIAL PRECEDENTS}

Throughout its history, Florida has seen various residential typologies and styles that hold valuable clues about the design of the contemporary Florida ZEH. Cracker Houses built by the early settlers in the 19th century were adapted to the climate over generations. The Mediterranean revival houses of the early 20th century were the beginning of an anti-climactic trend that still troubles us today. Sarasota School houses of the mid-20th century were designed in harmony with the environment promoting Florida's natural beauty and an indoor/outdoor lifestyle. The following is a brief discussion of these three influential housing types.

\subsection{The cracker house}

From the early 1800s, white settlers known as corn crackers began to trickle down from the northern states and establish homesteads in the Florida wilderness. Their houses became known as cracker houses. Like most homesteaders at the time, the crackers built walls by stacking pine logs on top of each other. Although the same type of dwelling was built across the country, the cracker house had features that were unique adaptations to the hot, humid Florida climate. In cold climates it was often much easier to place the logs directly on the ground or on a layer of foundation stones, but the cracker house was raised on piers to protect the wood from rotting on the moist, warm ground. In cold climates the floor was often made of earth, compacted into a slightly raised platform, which insulated the home during the cold winter months. In Florida, where air movement is essential to thermal comfort and the longevity of building materials, the floor was framed in wood and raised off of the ground so that air could circulate under the building. Although the northern dwellings had little or no roof overhang, the cracker house typically had a wide covered porch on one, two, or three sides that shaded the building from the hot sun and provided a covered, exterior space for work or leisure. As rooms were added, an outdoor space, or dogtrot, was left between the rooms, allowing air to move freely, making the indoor spaces more comfortable. In northern houses the cooking fire was also used to heat the house during the long cold winters. The cracker house had the kitchen in a separate building to keep the heat from the fire away from the living spaces. Cracker houses were built of wood and metal with low thermal mass and well suited to the Florida climate.

\subsubsection{The widdon cabin}

The widdon cabin built in 1864 and moved to its current location at the Forest Capital State Museum in Perry Florida in 1972, is a well preserved example of the typical cracker house design. 


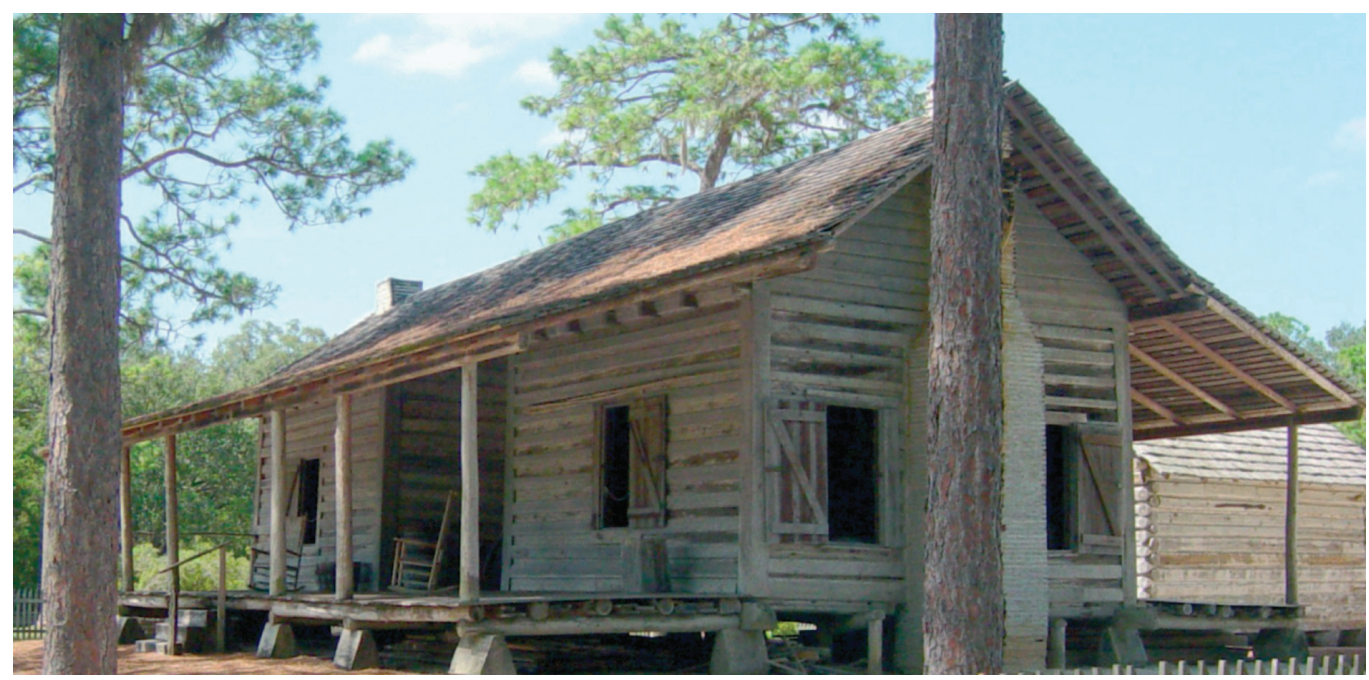

Figure 2: The widdon cabin. Photo by the Florida Capital State Museum.

The widdon house has a symmetrical layout with two $5.1 \mathrm{~m}$ square rooms and a $3.6 \mathrm{~m}$ wide dogtrot between them. Residents had to go outside when moving from room to room, reinforcing their connection with the surrounding environment. Breezes passing through the dogtrot create a negative pressure that pulls air out of the rooms, inducing natural ventilation through the house. A $3 \mathrm{~m}$ wide porch runs the entire length of the house on the North and South sides, creating a sense of spaciousness while providing outdoor living and work areas for the residents.

The house is elongated to the east and west allowing the sweeping roofs to provide shade throughout the day. The kitchen is in a separate building behind the main house to keep the heat from cooking away from the living spaces. Each room was equipped with a fireplace to provide heat in the winter when necessary [9].

\subsection{The Mediterranean revival style}

Despite the merits of the cracker house design, the group that drove development in Florida in its population boom of the late 19th and early 20th century was not the homesteaders, but the wealthy vacationers who began migrating to Florida in the late 1800s. Their numbers continued to grow during World War I when international travel was difficult and it became fashionable for the rich to build their wintering mansions in Florida. The architectural style of choice of these high society people was the masonry and stucco style of the exotic Spanish Mediterranean [10].With masonry walls and tile roofs that absorb heat, small windows that inhibit ventilation and small overhangs that allow the sun to bake the masonry walls, these houses were the antithesis of effective passive solar design in a hot, humid climate. But despite these faults, the Mediterranean revival style [Med-Rev] is still favored by many to this day and is one of the culprits responsible for Florida's high electricity demand.

\subsection{The Sarasota school}

One important exception to the Med-Rev trend happened in the early 1940s when a small handful of Ivy League trained architects brought their brand of modern, regional, functionalism to Sarasota, 


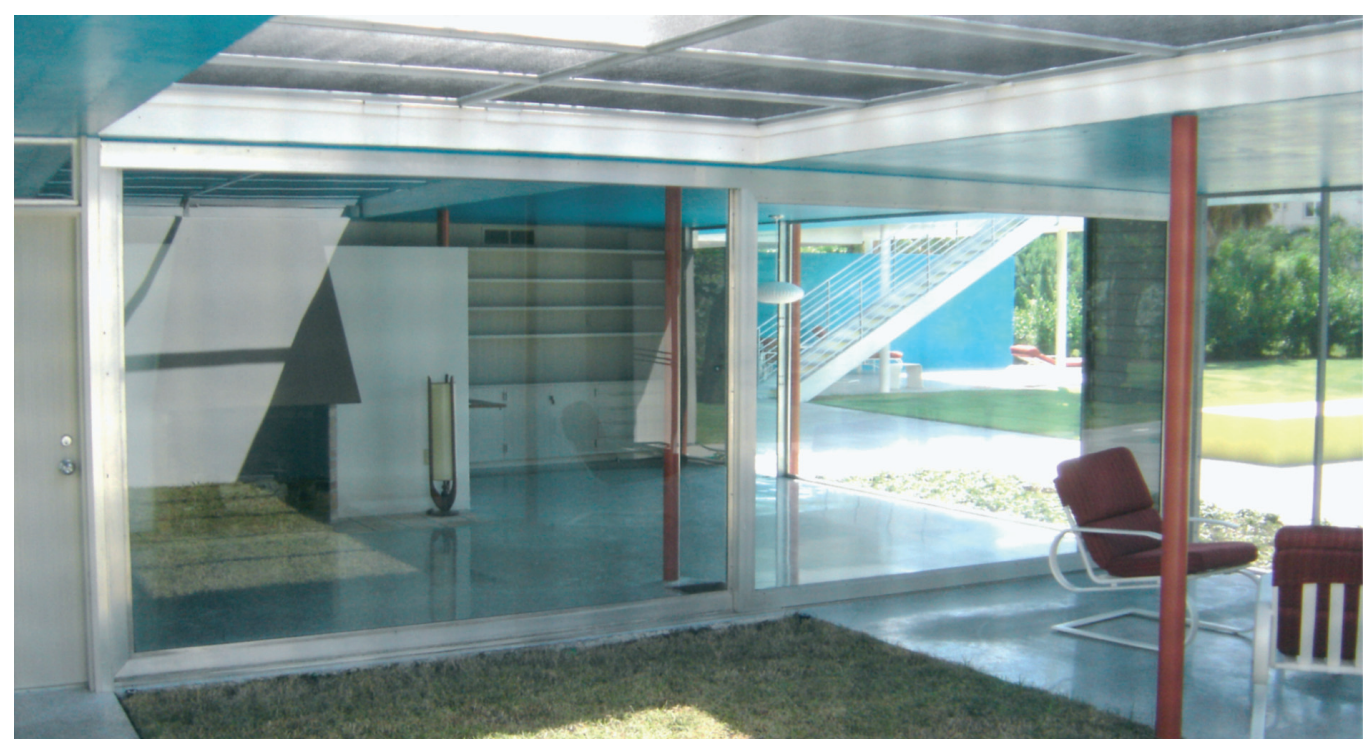

Figure 3: An indoor/outdoor space in Twitchell Rudolph house. Photo by Stanley Russell.

Florida to redefine Florida vernacular in a way that celebrated the region's environmental assets and responded to its climatic challenges.

Their work was so influential that it became known as the Sarasota school. Columbia University educated designer and builder Ralph Twitchell opened his office in Sarasota in 1936 after spending the early part of his career in New York and France. Twitchell saw Florida as a paradise and sought to design buildings that worked with and accentuated Florida's natural beauty. Twitchell situated himself to be the architect of choice for the wealthy progressive residents who were beginning to come to Sarasota to take part in its growing cultural presence. In the early 1940s Paul Rudolph graduated from Alabama Polytechnic Institute and went to work for Twitchell. While in Alabama, Rudolph had studied the climatic responses of local vernacular architecture and those ideas were fresh in his mind when he arrived in Florida to begin working with Twitchell [9]. The combination of environmental awareness, construction experience, and design savvy that the team possessed led quickly to works that brought them national attention.

\subsubsection{Sarasota school design strategies}

Twitchell and Rudolph houses were built with a modern vocabulary that was distinctly regional. The deep overhanging eaves, absent in the Med-Rev architecture of the day, were used to shade the building and to make shaded outdoor spaces recalling the cracker house design. Most houses included outdoor rooms enclosed with screens. Large sliding glass panels or louvered windows allowed entire walls to be opened for ventilation and to expand the interior space into the landscape. A variety of shading devices including louvers and screens helped protect the windows and walls from the hot Florida sun. In many cases the louvers were adjustable to respond to various sun angles or weather conditions, such as vertical storm shutters that pivoted up to become horizontal sun shading devices. The plans were elongated on the east west axis to allow cross ventilation in rooms and maximum shading for walls [11].The relevance of the Twitchell/Rudolf houses today lies in their skillfully conceived passive responses to the hot humid climate and their open planning and clean modern aesthetics that continue to suit contemporary tastes and lifestyles. As air conditioning 
became more prevalent in the 1950 s, however, the necessity and taste for climatically responsive architecture in Florida diminished. With the exception of a brief period of revived interest in the cracker house in the 1970s, little serious consideration was given to passive solar design and energy efficiency in Florida until the late 1990s.

\section{ZEH RESEARCH - THE LAKELAND PVRES}

In the state of Florida in the 1990s, the increasing affordability of PV technology began to open the door to site based electrical generation taking advantage of the state's wealth of insolation. In 1998, the Florida Solar Energy Center [FSEC] began its ZEH research program in collaboration with the DOE and the City of Lakeland municipal utility. The team constructed a $2400 \mathrm{sq}$. ft. energy-efficient photovoltaic residence [PVRES] and a standard model [the Control] with the same footprint and tested them both for more than a year (Fig. 4). In one year, the PVRES home used $6960 \mathrm{kWh}$ of electricity and had a PV system production of $5180 \mathrm{kWh}$. For the same year, the control used 22,600 $\mathrm{kWh}$ without any PV production. The yearly energy savings due to differences in energy efficiency of the two homes was 70\% for the PVRES house. Deducting the PV system's production, the PVRES house's net energy use for the entire year was only $1780 \mathrm{kWh}$, a $92 \%$ utility energy savings compared to the standard house.

Perhaps even more important than annual energy use is the fact that during periods of peak electric demand, the PVRES house placed nearly zero net demand on the utility system. Both test homes have R-30 fiberglass insulation blown in the attic, but there are major differences in the building envelope and mechanical systems of the two buildings.

\subsection{The building envelope}

The building envelope of the PVRES house features a 77\% reflective white concrete tile roof. The control home's roof is made of conventional, $7 \%$ reflective gray asphalt shingles. When the outside

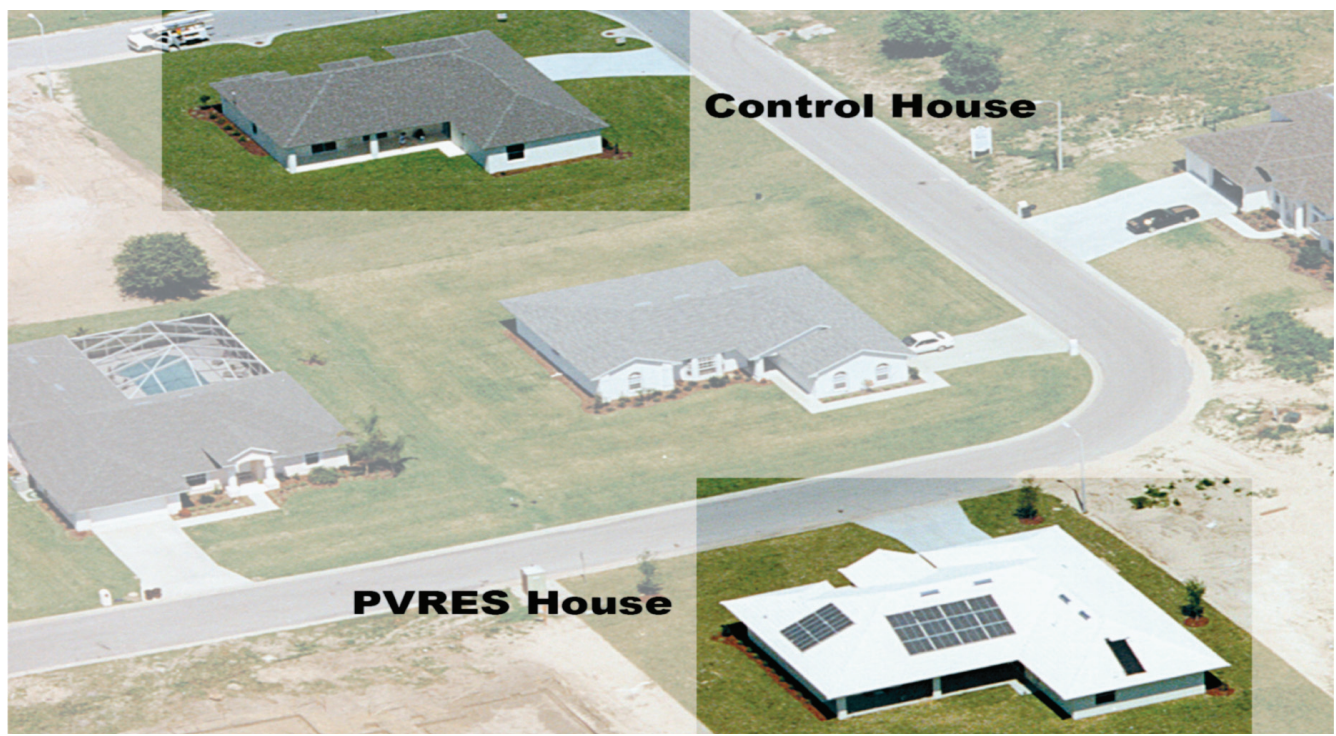

Figure 4: The Lakeland PVRES project. 
summer air temperatures were at their peak, the coincident peak attic air temperature was $131.5^{\circ} \mathrm{F}$ in the control house and $91.4^{\circ} \mathrm{F}$ in the PVRES. The PVRES home has a 3 foot wide overhang around the entire perimeter of the building, whereas the standard home has a one and a half foot roof overhang. At 11:10 AM on October 1st, 1997 the standard home, with a 1.5 foot overhang casts a shadow length of just 36 inches down the wall. At the same time, the shadow cast on the PVRES home is nearly 72 inches long. The overhang of the PVRES home shades most of the wall and at least $75 \%$ of the south and east window area. In conventional residential construction in Florida, walls are insulated with R-3 to R-5 insulation on the interior, exposing the exterior to the hot sun and ambient air temperature and allowing the masonry to store excess heat and pass it slowly to the interior spaces. Conversely, the concrete block walls of the PVRES home were covered with R-10 insulation on the exterior to keep the masonry from absorbing excess heat from the outside. The thermal mass of the masonry was exposed to the interior to assist the air conditioning system in cooling the interior space. The masonry is pre-cooled by the AC during the daytime hours when solar availability is high and the PV system output is at its maximum. In the late afternoon and evening when there is little PV output, the pre-cooled masonry begins to absorb heat from the interior, reducing the cooling load and the amount of energy required to power the AC system. The windows in the PVRES home have low-E glass with Argon gas fill, a SHGC of 0.38, and a daylight transmittance of $73 \%$. The improved glazing performance reduces the size for the air conditioning system when compared to single pane windows. With 384 square feet of glass in the floor plan there is a 7,700 Btu/hr difference (0.64 tons) in the required size of the air conditioning system.

\subsection{The mechanical systems}

The mechanical systems of the two buildings also had marked differences. The HVAC systems were designed based on a $95^{\circ} \mathrm{F}\left[35^{\circ} \mathrm{C}\right]$ outdoor design temperature with a $75^{\circ} \mathrm{F}\left[24^{\circ} \mathrm{C}\right]$ interior temperature. The calculations indicated a 3.88 ton cooling system for the standard home (4 tons) and 1.73 ton (2 tons) for the PVRES house. A two-ton heat pump and a variable speed indoor air handler with a combined seasonal energy efficiency ratio (SEER) of $14.4 \mathrm{Btu} / \mathrm{W}$ were selected to provide optimum efficiency, humidity removal, and quiet operation. For the standard home, a standard efficiency 4-ton heat pump with a SEER of $10.0 \mathrm{Btu} / \mathrm{W}$ was used. In conventional Florida house construction, the ducts and often the air-handler are located in an un-insulated attic space. In Florida, the attic sometimes reaches $130^{\circ} \mathrm{F}$, and studies show that heat transfer to the duct system can reduce the cooling capacity of the air conditioner by $30 \%$. In the PVRES house the air-handler and ductwork are placed within the conditioned space of the building. Any heat gained by the duct system is removed from the conditioned space itself so there is no reduction in cooling capacity of the air conditioner. To avoid problems with leakage, the duct system was carefully sealed with mastic and tested. The duct system was oversized to provide better air flow across the evaporator, reduce air handler fan power, improve system efficiency, and reduce noise.

\subsection{Hot water}

The PVRES home uses a solar water heating system with propane back up. The system consists of a 40 square foot solar collector mounted on the south side of the home's roof. The collector is rated at an energy production of $45,600 \mathrm{Btu} /$ day at the low temperature $\left(95^{\circ} \mathrm{F}\right)$ rating. The control home contains a standard electric resistance 52 gallon storage tank in the garage rated to use $4,828 \mathrm{kWh} / \mathrm{year}$. The PVRES water heater has a rated energy factor of 0.65 with the measured hot water temperature of $130^{\circ} \mathrm{F}$ at the tap. Approximately $66 \%$ of the system's water heating is solar and the remainder is 
supplied by propane gas. Daily hot water use averaged 37.8 gallons against a daily propane consumption of only $3.2 \mathrm{ft}^{3}$ or 0.09 gallons per day.

\subsection{PV array}

The PV generation system for the PVRES was sized to provide power that would offset most of the daytime household electrical loads. Based on the predicted loads for a peak day, it was determined that a $4 \mathrm{~kW}$ solar array should be installed. As a Utility Interactive System, the PV system is owned and maintained by the electric utility company and the power generated is supplied to the utility side of the meter. The output of the system was monitored by the utility company to evaluate the system performance and to troubleshoot problems. Systems installed such as this one increase the capacity of a service provider and can help reduce the total operating hours required for fuel-burning generators. The PV arrays were installed in panels, comprised of three $75 \mathrm{w}$ modules each and connected in series. Thirty-six modules or 12 panels make up the south-facing sub-array and 18 modules or six panels were installed on the west face of the roof. An AC power inverter was selected to convert the array's DC power to AC for interaction with the utility grid [12].

\section{EMERGING TECHNOLOGIES}

The worldwide sustainability movement has stimulated research and development of many new materials and products that will be useful in building the ZEH of the future. Scanning the web one is overwhelmed by the number and diversity of products already available or under development that will vastly change the way that we build and live in the near future. The scope is too broad to cover here, so the following is a description of a few of the technologies that show promise for use in the Florida ZEH.

\subsection{Site-based clean renewable energy}

In early examples of ZEH, PV technology has been the primary source of site generated renewable energy in most locations. PV is more efficient in geographic locations with high insolation and less efficient in locations where cloudy weather is prevalent. Likewise, other potential renewable energy sources tend to favor certain climates, economies or geographic locations over others so a variety of renewable energy sources is necessary to provide for the diverse conditions existing in the world. In addition to PV, geothermal, wind, biomass, and hydrogen fuel cells all hold the promise of clean renewable energy although site based applications are still in the developmental stages. Among these, PV, biomass, and hydrogen fuel cells are particularly well suited to Florida's situation. Projects funded by the Florida Energy Systems Consortium are currently looking at ways of increasing the efficiency of thin film PV, turning biomass into liquid fuels, and developing hydrogen batteries for energy storage and hydrogen production in off grid ZEH situations. At Florida State University an off grid zero energy building [OGZEB] utilizes hydrogen batteries to store power from the PV array and for hydrogen production. The hydrogen produced can be used in hydrogen burning appliances, and electricity generating, hydrogen fuel cells. These technologies are not yet commercially available but are nearing that stage.

\subsection{Insulation}

To minimize the need for energy in buildings, insulation systems are critical, and several promising materials are on the horizon. Aerogel, a material first discovered in the 1940s, is made by drying the liquid contents from a gel without collapsing or shrinking its matrix structure. Referred to as solid 
smoke, an aerogel consists of more than $96 \%$ air, whereas the remaining $4 \%$ is a matrix of silica (silicon dioxide), a principal raw material for glass. Aerogels are extremely light weight but despite their lack of substance, they are excellent solid insulators, transmitting only $1 / 100$ th the heat of normal glass. Aerogels can be fabricated in slabs, pellets, or most any shape desirable, and have a range of potential uses. By mass or by volume, sandwiched between two layers of glass, transparent compositions of aerogels make possible double-pane windows with high thermal resistance. Aerogels are a more efficient, light-weight, and less bulky form of insulation than the polyurethane foam currently used for building insulation. Products utilizing aerogels including roofing, glazing, and exterior wall and roof panels are currently in commercial production [13].

\subsection{Windows}

Windows are among the largest contributors to heat loss from buildings, and research is being conducted on alternative films and glasses that help window assemblies achieve higher $\mathrm{R}$ values. One of the most promising emerging window technologies uses the everyday thermos, one of the most effective and accessible means known of preventing heat loss, as its inspiration. Because heat is conducted by three modes, conduction, convection, and radiation, a thermos insulates by separating the contents from the outside temperature with a vacuum that prevents conduction and convection, and a reflective coating in the thermos bottle that serves to reflect radiated heat back to its source. Similarly, windows with double pane glass and a vacuum between the panes can stop conduction and convection while low-e coatings reduce radiation. The assembly has the potential to provide insulation values of R-10 to R-12 compared to a standard double-pane window with an R-value of 3 or 4 [14].

\subsubsection{Electro-chromic glass}

Window assemblies using electro-chromic glass, also known as smart windows, regulate the amount of heat that passes through them by darkening or lightening with a chemical reaction. Depending on the type of sensor attached, windows could be made to automatically darken or lighten according to the outdoor air temperature or the intensity of the sun. Widespread use of electro-chromic windows has the potential to significantly lower the country's energy consumption and to make ZEH more affordable by reducing the amount of PV necessary to power a home. Electro-chromic glass is still in the development stages and reducing the cost and increasing the panel size remain the biggest challenges [15].

\subsection{Thin film PV material}

Advances in PV thin film technology have made building integrated PV [BIPV] systems a reality in recent years, and this technology promises to become more affordable in the near future. While producing renewable energy from the sun, these systems are more versatile than traditional PV panels. Design, aesthetics, and functionality are all integrated into the finish materials of the building. BIPV is currently available in roofing, siding, and glazing systems, and the NREL reports that 'future module efficiencies are expected to climb close to the state-of-the-art of today's best cells, or to about $10-16 \%$ '. Costs are expected to drop to below $\$ 100 / \mathrm{m}^{2}$ in volume production, and could reach even lower levels - well under $\$ 50 / \mathrm{m}^{2}[16]$.

\subsection{Lighting}

Lighting is one of the top three building energy end uses, and efficient lighting systems are critical to the operation of energy efficient buildings. A light emitting diode (LED) is a semiconductor 
device, which converts electricity into light. LED lighting has been around since the 1960s, but is just now beginning to appear in the residential lighting market. LEDs are small in size, but can be grouped together for higher intensity applications. A recent life cycle analysis [LCA] done by Osram corporation reveals that LEDs perform on par with compact fluorescents [CFL] and $98 \%$ of their energy goes to lighting, whereas only $2 \%$ goes into their manufacture. The study showed that LED and CFL lamps use $700 \mathrm{kWh}$, whereas an incandescent lamp uses 3,300 kWh during a designated 25,000 hr period. LED technology is still developing, and LED LCA will continue to improve in the future [17].

\subsubsection{OLED lighting}

Hundreds of millions of dollars have been invested in organic light emitting diode [OLED] lighting research, especially in Europe, the United States, and Japan. Still early in the development stage, currently, more than 130 companies and universities, and over a dozen organizations are working on OLED lighting. Compared with the other major lighting technologies in the market such as incandescent, fluorescent, high intensity discharge lamps, LEDs, and electroluminescent, OLED lighting has several advantages. OLED lighting devices emit from the surface, can be made flexible, rollable, and even transparent like a window or reflective like a mirror. OLED lighting is thin, rugged, lightweight, and has fast switch-on times, wide operating temperatures, no noise, and is environmentally friendly. The power efficiency of OLED lighting has also improved dramatically. The unique features of OLED lighting are inspiring the imagination of designers, who are exploring various OLED lighting applications including windows, curtains, automotive light, decorative lighting, and wallpaper. OLED lighting can have very attractive designs, can be rigid or flexible, white or color, or tunable. OLED lighting does not have ultraviolet or infrared in its spectrum, and does not generate heat during operation [18].

\subsection{Cooling}

Cooling is the largest energy end use in buildings in a hot humid climate. Heat pumps have been used in Florida for some time because of the region's relatively small seasonal temperature changes that allow for higher efficiencies. Geothermal heat pumps are similar to ordinary heat pumps, but use the ground instead of outside air to cool the condenser while providing heating, air conditioning, and, in some cases, hot water. Because of the high ground temperatures in Florida, the benefits of using the earth as a heat sink are less than in northern latitudes where cooler ground temperatures dissipate heat more readily. By using the same heat sink principal but changing the sink to water or phase change materials instead of earth, heat is kept in the system and is used to generate hot water for the house. In addition, piping a cooling or heating medium from the source equipment to fan coil units placed throughout the house allows integration with a solar thermal system, and for localized temperature control, increased comfort, and lower energy consumption when compared with a conventional, centralized, forced air system.

\subsubsection{Absorption chiller}

Conventional air conditioning units use large amounts of electricity to power a compressor for pressurizing refrigerant. An absorption chiller or refrigerator replaces the compressor with an absorption device that induces evaporation through absorption and uses a heat source, such as natural gas, or solar thermal to regenerate the absorbent by evaporating the refrigerant from the saturated absorbent/refrigerant mixture. Although absorption coolers require electricity for pumping the refrigerant through the system, the amount of electricity is small compared to that consumed by a compressor 
in a conventional air conditioner or refrigerator unit. Absorption chillers have been in use for a long time in large commercial applications where cooling towers are necessary, but recently compact absorption chillers that do not require a cooling tower have become available for residential purposes. Manufacturers claim that compact absorption chillers can operate on temperatures as low as $140^{\circ} \mathrm{F}$, well within the range of commercially available solar thermal systems [19].

\subsection{Desiccant dehumidification}

High humidity places a heavy load on conventional air conditioning equipment because the incoming air must be cooled below the dew point to remove its moisture. This chilled air must then be reheated to bring it back to room temperature, consuming extra energy and increasing peak energy demands. Desiccant materials that remove moisture from incoming air can be added to an HVAC system to reduce the energy demand for dehumidification. Desiccants enable independent control of temperature and humidity, improving HVAC system efficiency by freeing cooling components from the dehumidification function allowing them to run at more efficient operating points. Liquid desiccant systems coupled with solar thermal arrays for regeneration of the desiccant materials have the potential to significantly reduce the amount of energy required for cooling while regulating the humidity level of indoor air [20].The NREL is currently testing cutting edge polymer desiccant membranes that hold the promise of enabling highly efficient air conditioning systems.

\section{CONCLUSION}

The Lakeland project and several other projects over the past 12 years have shown that houses with a well-designed building envelope, energy efficient mechanical systems and appliances, and a solar array can achieve near net zero or net zero energy consumption when averaged over the course of a year. As utility interactive systems, entire subdivisions of ZEH could reduce the loads on local utilities and the need for environmentally disruptive or damaging methods of electrical generation. Although many important discoveries and innovations have been made to date, there has been little consideration given to the potential for passive cooling during Florida's mild temperature seasons. A hybrid, open and closed building type, that marries cutting edge technology with age old vernacular wisdom, would significantly reduce energy demand with the added benefit of reconnecting people to the natural environment. Based on the research articulated above, several strategies for designing a Florida ZEH have become clear.

\subsection{Strategies for a Florida ZEH - Clean renewable energy}

At this time PV panels are the best choice for site based clean renewable energy production. Photovoltaic technology is evolving quickly and the best choice of components at any given time requires some research. At this time conventional panels still offer the best combination of performance and affordability, but that is almost certain to change in the near future. Significant research is currently being done on BIPV technology. BIPV will continue to improve as an option as prices come down and efficiencies improve. As hydrogen and biomass conversion technologies mature, they will also offer a source of site-based clean renewable energy to Florida homes. Florida is largely urbanised so the need for off-the-grid ZEH which require expensive batteries is not that great. The grid tied ZEH offers many advantages to the individual resident and the community as a whole. In the grid tied scenario, residents do not need storage batteries for their homes, they can rely on municipal power whenever necessary, and they can get income from any excess power that they sell back to the utilities. The community as a whole benefits from smaller size central utilities and a cleaner environment. 


\subsubsection{Shade}

As our precedents proved, shade is a crucial element of a Florida residence. The outdoor living space of the cracker house was made habitable by the broad overhanging roofs that provided shade throughout the day. The Twitchell, Rudolph houses invariably had wide overhangs and shading devices to shade walls and indoor/outdoor living spaces. The PVRES house had wide overhangs that shaded $75 \%$ of the walls and glass during the entire day. Shading devices should be adjustable so that the winter sun can be used for passive solar heating when necessary. The reduced energy demand resulting from well-designed shading devices would contribute to the overall efficiency and economy of the Florida ZEH.

\subsubsection{Air movement}

In Florida's climate with high humidity, air movement is critical to creating a sense of comfort. The cracker house was designed to let air move through under and around the living spaces. Twitchell Rudolph houses had entire walls that could open, allowing the breeze to flow through. Early examples of ZEH, however, have focused on a controlled closed system to maintain a constant comfort range on the interior spaces. A Florida ZEH could be designed so that the walls can open on all sides allowing air to move through the interior spaces during the mild temperature months in the fall and spring. Natural passive cooling would conserve energy and give residents an enhanced sense of connection with the environment.

\subsubsection{Light, reflective building materials}

Because of the intensity of the sun and the small diurnal temperature change, a Florida ZEH should use reflective materials and materials with a low thermal mass that do not absorb and retain heat. As shown by the Lakeland project, a reflective roof surface alone can make a $40^{\circ}$ temperature difference in an attic space. Materials with high thermal mass absorb heat and release it slowly to the interior of the building increasing the cooling load on the mechanical systems. Materials like wood or metal give up their heat quickly in the evening and do not put any extra cooling load on mechanical systems.

\subsubsection{Appropriate mechanical systems}

Because of their potential affinity with solar thermal systems, small absorption chillers and heat pumps can be good choices for the Florida ZEH. They can both be combined with a solar thermal system to pipe hot or cold water to fan coil units in the house taking full advantage of Florida's solar radiation. An energy recovery ventilator [ERV] can be used to preheat or cool supply air for the system improving efficiency and indoor air quality. A desiccant system working in conjunction with the ERV dehumidifies the air improving thermal comfort, indoor air quality, and efficiency of the HVAC system.

\subsubsection{Lighting}

Florida ZEH would benefit in several ways from having energy efficient lighting fixtures. The energy required to power CFL and LED is a fraction of that required by incandescent fixtures and the lifespan is longer. CFL and LED fixtures produce much less heat than incandescent bulbs allowing air conditioning systems to run more efficiently and increasing comfort during times when the house is being naturally ventilated.

\section{ACKNOWLEDGMENT}

The research presented in this paper was funded by a Florida Energy Systems Consortium [FESC] grant. 


\section{REFERENCES}

[1] D\&R International, Ltd, 2008 Buildings Energy Data Book, DOE website PDF, 2008, available at http://buildingsdatabook.eren.doe.gov/

[2] Solar houses: Solar IV, MIT Libraries website, Cambridge, MA, available at http://libraries. mit.edu/guides/subjects/architecture/architects/solar/solar4.html

[3] Mazria, E., The Passive Solar Energy Book, Rodale Press: Emmaus, PA, 1979.

[4] Lstiburek, J., Westford House, Building Science Insight, Building Science.com, 2009, available at http://www.buildingscience.com/documents/insights/bsi-018-westford-house/

[5] Wotzak, R., The First U.S. Passive House Shows That Energy Efficiency Can Be Affordable, Green Building Advisor.com, 2009, available at http://www.greenbuildingadvisor.com/homes/ first-us-passive-house-shows-energy-efficiency-can

[6] Parker, D.S., Very Low Energy Homes in the United States: Perspectives on Performance From Measured Data, PDF, Florida Solar Energy Center website, Cocoa, FL, 2008, available at http://www.fsec.ucf.edu/en/publications/publist.php?dept=br

[7] Biello, D., New solar-cell efficiency record set, Scientific American, 2009, available at http://www.scientificamerican.com/blog/post.cfm?id=new-solar-cell-efficiency-recordse-2009-08-27

[8] US Department of Energy Solar energies Technology Program, available at http://www1.eere. energy.gov/solar/plans_implementation_results.html\#program_overview

[9] Hasse, R.W., Classic Cracker: Florida's Wood Frame Vernacular Architecture, Pineapple Press Inc.: Sarasota, FL, 1992.

[10] Howey, J., The Sarasota School of Architecture, MIT Press: Cambridge, MA, 1995.

[11] Domin, C. \& King J., Paul Rudolph the Florida Houses, Princeton Architectural Press: New York, 2002.

[12] Florida Solar Energy Center, ZEH: Lakeland Fl., Orlando, FL, 2007, available at http://www. fsec.ucf.edu/en/research/buildings/zero_energy/lakeland/

[13] Kahn, J., Aerogel Research at LBL: From the Lab to the Marketplace, Berkeley Lab science Articles Archive, Berkeley, CA, 1991, available at http://www.lbl.gov/Science-Articles/ Archive/aerogel-insulation.html

[14] Marinov, O.I., New Generation of Architectural Glazing Vacuum Insulated Glass Units, available at http://www.glassfiles.com/library/search.php?search=Vccume+insulated+glass\&page $=2$

[15] NREL, Elecrochromic Research Activities, NREL website, 2010, available at http://www.nrel. gov/buildings/electrochromic_activities.html

[16] NREL, Thin Film Partnership Program, NREL website, 2010, available at http://www.nrel. gov/pv/thin_film/

[17] Life Cycle Assessment of Illuminants A Comparison of Light Bulbs, Compact Fluorescent Lamps and LED Lamps, OSRAM Opto Semiconductors GmbH, Siemens Corporate Technology, available at http://www.osramos.com/osram_os/EN/About_Us/We_shape_the_future_of_light/Our_ obligation/LED_life-cycle_assessment/OSRAM_LED_LCA_Summary_November_2009.pdf

[18] Colegrove, J., OLED Lighting Set to Take offin 2011, LEDS Magazine, Pennwell Corporation, Tulsa, OK, May/June 2009, available at http://www.ledsmagazine.com/features/6/6/6

[19] Mittelbach, W. \& Jakob, U., Development and investigation of a compact silica gel/water absorption chiller integrated in solar cooling systems. VII Minsk International Seminar, Minsk, Belarus, 2008, available at http://www.solarnext.eu/pdf/ger/publications_presentations/jakob/08MinskIntSeminar_Compact_SilicaGel_Water_Adsorption_Chiller.pdf

[20] Oberg, V. \& Goswami, Y., Performance Simulation of Solar Hybrid Liquid Desiccant Cooling for Ventilation and Preconditioning, University of Florida, Gainesville, FL, 1998, available at http://cerc.eng.usf.edu/publications/Goswami/Liquid\%20Desiccant/1998\%20Oberg\%20 and\%20Goswami\%202.pdf 
